\title{
Comprehensive behavioral characterization of an APP/PS-1 double knock-in mouse model of Alzheimer's disease
}

\author{
Scott J Webster ${ }^{1}$, Adam D Bachstetter ${ }^{1}$ and Linda J Van Eldik ${ }^{1,2^{*}}$
}

\begin{abstract}
Introduction: Despite the extensive mechanistic and pathological characterization of the amyloid precursor protein (APP)/presenilin-1 (PS-1) knock-in mouse model of Alzheimer's disease (AD), very little is known about the ADrelevant behavioral deficits in this model. Characterization of the baseline behavioral performance in a variety of functional tasks and identification of the temporal onset of behavioral impairments are important to provide a foundation for future preclinical testing of AD therapeutics. Here we perform a comprehensive behavioral characterization of this model, discuss how the observed behavior correlates with the mechanistic and pathological observations of others, and compare this model with other commonly used AD mouse models.

Methods: Four different groups of mice ranging across the lifespan of this model (test groups: 7, 11, 15, and 24 months old) were run in a behavioral test battery consisting of tasks to assess motor function (grip strength, rotor rod, beam walk, open field ambulatory movement), anxiety-related behavior (open field time spent in peripheral zone vs. center zone, elevated plus maze), and cognitive function (novel object recognition, radial arm water maze).
\end{abstract}

Results: There were no differences in motor function or anxiety-related behavior between APP/PS-1 knock-in mice and wild-type counterpart mice for any age group. Cognitive deficits in both recognition memory (novel object recognition) and spatial reference memory (radial arm water maze) became apparent for the knock-in animals as the disease progressed.

Conclusion: This is the first reported comprehensive behavioral analysis of the APP/PS1 knock-in mouse model of AD. The lack of motor/coordination deficits or abnormal anxiety levels, coupled with the age/disease-related cognitive decline and high physiological relevance of this model, make it well suited for utilization in preclinical testing of AD-relevant therapeutics.

Keywords: Alzheimer's disease, amyloid precursor protein/presenilin-1, motor behavior, anxiety behavior, cognition, learning and memory, spatial reference memory, recognition memory, transgenic mouse model

\section{Introduction}

A large number of mouse models have been genetically engineered in attempts to model different aspects of the etiology and pathology of Alzheimer's disease (AD). While all transgenic mouse models generated to date fail to replicate completely the pathology observed in human $\mathrm{AD}$, they have offered valuable insight into the

\footnotetext{
* Correspondence: linda.vaneldik@gmail.com

'Sanders-Brown Center on Aging, 800 S. Limestone, University of Kentucky, Lexington, KY 40536, USA

Full list of author information is available at the end of the article
}

molecular mechanisms of AD and have provided a useful preclinical platform with which to test potential $A D$ therapeutics [1]. Many of the currently used AD mouse models are generated by random exogenous insertion of genetic material into the host genome to produce overexpression of a particular protein of interest. While this approach is relatively straightforward and provides a convenient way to examine a gene/protein of interest, ectopic overexpression of a gene can lead to off-target complications unrelated to the disease process that can complicate experiments aimed at evaluating novel $A D$

\section{Biomed Central}


therapeutics. For example, ectopic overexpression of even a wild-type (WT) transgene can evoke cellular, anatomical, and behavioral abnormalities [2-7]. One way to bypass these off-target complications common to transgenic mice is to knock-in (KI) the gene of interest into a specific genetic locus in the mouse genome.

The APP ${ }^{\mathrm{NLh} / \mathrm{NLh}} \times \mathrm{PS} 1^{\mathrm{P} 264 \mathrm{~L} / \mathrm{P} 264 \mathrm{~L}}$ double gene-targeted knock-in (APP/PS1 KI) mouse takes advantage of this KI gene-targeted insertion with selective point mutations in amyloid precursor protein (APP) and presenilin1 (PS-1) genes linked to familial AD pathology [3,8-11]. In general, the use of the genetic KI strategy potentially increases the fidelity of a model system of a relevant disease process. A case in point is the APP/PS1 KI mouse, which replicates much of the amyloid-dependent pathologies seen clinically in AD. For example, nearly identical profiles of amyloid processing exist between observed AD patients and these APP/PS1 KI mice [12]. Further, these mice exhibit progressive amyloid deposition starting at 6 months of age that increases linearly over time, so that by 18 months of age they show many dense amyloid deposits in regions such as the hippocampus and dentate gyrus [11-14]. These amyloid depositions consist of both neuritic and non-neuritic plaques with high similarities to those seen in human AD [12]. Other observed pathological changes for this model that are relevant to the pathogenesis of $\mathrm{AD}$ include: increased oxidative stress and metabolic disturbances starting as early as 1 to 2 months of age, reduction of neuronal L-type calcium channel activity in 14-month-old mice, impaired hippocampal LTP, and age-related increases in reactive gliosis and proinflammatory cytokine production [11-13,15-17].

Despite the extensive biochemical and mechanistic characterization of this APP/PS1 KI mouse model, less is known about AD-relevant behavioral/cognitive deficits of this model. One report describes cognitive deficits in 14-month-old APP/PS1 KI mice in a one-way active avoidance task [16]. Another study showed an agedependent cognitive impairment in a Stone T-maze task [18]. However, to date a comprehensive behavioral analysis of this AD model has not been reported. Little is therefore known about the baseline behavioral profile and the temporal onset of behavioral impairments in this APP/PS1 KI model in a series of standard behavioral tasks. Here we seek to fill this void in knowledge by examining the cognition/behavioral profile (motor behavior, anxiety-related behavior, and cognitive function) across the lifespan of the APP/PS1 KI mouse using a cross-sectional design (age groups of 7, 11, 15, and 24 months old). We report here that the APP/PS1 KI mouse shows no motor deficits or abnormal anxiety levels at any of the ages tested. In addition, the APP/ PS1 KI mouse shows an age-dependent development of cognitive deficits in two different memory domains relevant to $A D$ : spatial reference memory and recognition memory [19-21].

\section{Methods}

Mice

Four different age groups $(7,11,15$, and 24 months) of $\mathrm{APP}^{\mathrm{NLh} / \mathrm{NLh}} \times \mathrm{PS} 1^{\mathrm{P} 264 \mathrm{~L} / \mathrm{P} 264 \mathrm{~L}}$ mice were used in this study. This mouse model was originally developed at Cephalon [11] using gene-targeted KI technology to introduce the Swedish FAD K670N/M671L point mutations, humanize the mouse $\beta$-amyloid sequence (NLh), and introduce a proline to leucine (P264L) mutation in the mouse PS-1 gene $[8,9]$. A useful characteristic of this model is that because an endogenous promoter drives the expression of each gene, development of ADlike pathology occurs in the absence of APP or PS1 overexpression. Mice were maintained on a CD-1/129 background, and WT mice were obtained from heterozygous APP-PS1 mating pairs and maintained as a separate line for more than 20 generations of inbreeding, for use as controls. All mice were genotyped by PCR analysis of tail-snip DNA to monitor for the maintenance of the appropriate genotype [22].

Animal protocols followed the principles and practices outlined in the Guide for the Care and Use of Laboratory Animals, and were approved by the Institutional Animal Care and Use Committee of the University of Kentucky. All behavioral testing was performed in the University of Kentucky Rodent Behavior Core. There were no observable differences in mortality rates between genotypes in this study, and behavioral data for both genders were combined after observing no differences between the behavioral responses of male and female mice for any age group tested.

\section{Grip strength}

Forelimb grip strength was measured in grams of resistance using a digital force-gauging apparatus (Animal Grip Strength System; San Diego Instruments, San Diego, CA, USA). Forelimb strength was measured by holding the mouse by the nape of the neck and by the base of the tail. The forelimbs were placed on the tension bar pad, and the mouse was pulled back gently until it could no longer grip the bar and was forced to release its hold on the grip pad. The resistance was automatically calculated in real time with the digital force-gauging apparatus and the maximal resistance achieved by each mouse was reported as the final grip strength.

\section{Rotor rod}

The mice were placed on a rotating rod $(3.18 \mathrm{~cm}$ diameter) in lanes $11.5 \mathrm{~cm}$ wide to maintain the animal in 
the same direction while the bar is rotating (ROTORRODTM System; San Diego Instruments). The bar is $46 \mathrm{~cm}$ from the floor of the apparatus and the bar's speed of rotation was gradually and linearly increased from 0 to $40 \mathrm{rpm}$ across the 5 -minute trial. Both the latencies (seconds) and the distance $(\mathrm{cm})$ at which the mice were able to maintain their balance on the bar were then recorded automatically using beam break technology.

\section{Beam walk}

The beam walk protocol used in this study has previously been described [23]. Briefly, mice were trained to walk along an $80 \mathrm{~cm}$ long and $3 \mathrm{~cm}$ wide beam elevated $30 \mathrm{~cm}$ above the bench by metal supports to reach an enclosed goal box. Mice were placed on the beam at one end and allowed to traverse the beam to reach the goal box. This was repeated using decreasing size $(3 \mathrm{~cm}, 2 \mathrm{~cm}$, and $1 \mathrm{~cm})$ beams. Foot slips were scored when one or both hind limbs slipped from the beam.

\section{Open field activity}

Mice were placed in a multi-unit open field maze (San Diego Instruments) with field chamber $(50 \mathrm{~cm}$ long $\times$ $50 \mathrm{~cm}$ wide), and activity was recorded using EthoVision $\mathrm{XT} 8.0$ video tracking software (Noldus Information Technology, Leesburg, VA, USA). Each $50 \mathrm{~cm} \times 50 \mathrm{~cm}$ unit was digitally divided into 25 quadrants of equal size (nine central and 16 peripheral) using EthoVision XT 8.0 video tracking software. The nine central quadrants are collectively referred to as the center zone and the 16 peripheral quadrants are collectively referred to as the peripheral zone as previously described [24]. Data were collected continually for 30 minutes and the distance traveled $(\mathrm{cm})$, velocity $(\mathrm{cm} /$ second $)$, and time spent in the center zone versus the peripheral zone were all recorded and scored automatically. The open field task is a popular model for assessing ambulatory movement and anxiety-like behaviors in response to a novel environment. Distance traveled and movement speeds are measures of ambulatory movement, whereas the amount of time spent in the center zone versus the peripheral zone is a measure of anxiety levels due to the rodent's natural thigmotaxis behavior when frightened [25].

\section{Elevated plus maze}

An elevated plus maze (San Diego Instruments) was used to assess anxiety-related behavior in response to a potentially dangerous environment. The elevated plus maze consists of four arms (two enclosed arms and two open arms) elevated $100 \mathrm{~cm}$ above the floor. Anxietyrelated behavior was defined as the degree to which the subject avoided the open arms (perceived unsafe arms) of the maze, preferring the closed arms (perceived safe arm) of the maze. Each mouse was placed in the center of the maze and the amount of time spent in each arm was recorded automatically by EthoVision XT 8.0 video tracking software (Noldus Information Technology).

\section{Radial arm water maze}

The radial arm water maze (RAWM) task can be used to measure both spatial working memory [26,27] and spatial reference memory. The maze procedure used in this study was designed as a rapid measure of spatial reference memory and has been previously described in detail [28]. Briefly, the maze consisted of six arms $160 \mathrm{~cm}$ in diameter with arm length $30 \mathrm{~cm}$ and common circular swim area of $40 \mathrm{~cm}$. The pool was filled with water until the level was approximately $2 \mathrm{~cm}$ above (covering) a clear (invisible) 10-cm circular platform. The platform was placed in the back of an arm approximately $7 \mathrm{~cm}$ away from the side and back walls. The pool was located in the center of a room and enclosed by a black curtain. Geometric extra-maze visual cues were fixed throughout the study on three sides of the curtains.

The RAWM protocol consisted of a 2-day testing paradigm. A staggered training schedule was used, running the mice in cohorts of five or six mice, while alternating the different cohorts through the trials over day 1 and day 2 of the test. This alternating protocol was used to avoid the learning limitations imposed by massed subsequent trials and to avoid fatigue that may result from consecutive trials. During block 1 (six trials) and block 2 ( ix trials), mice were trained to identify the platform location by alternating between a visible and a hidden platform in the goal arm, with three hidden platform trials and three visible platforms. Block 3 consisted of three trials all with a hidden platform. For day 2, mice were tested in three blocks of five trials each (15 total trials), with only the hidden escape platform employed, forcing the mice to use a spatial strategy to identify the goal arm location.

Data are presented as the average errors per block, similar to the methods described in [28], and only errors during the hidden platform trials are included in the analysis, as they represent the spatial memory component of the RAWM task. Errors were scored each time the subject entered the arm not containing the platform. An arm entry was defined as the mouse's whole body moving past the threshold of the entrance to an arm. After reaching the platform, the mouse was allowed to remain on it for 10 seconds and was then removed, dried, and placed in a warming cage until the initiation of that mouse's next trial. For each subsequent trial the mouse was released from a different start arm into the maze and allowed to locate the platform. Platform location remained constant throughout testing. RAWM performance was recorded and scored 
using EthoVision XT 8.0 video tracking software (Noldus Information Technology). Every arm entry for each animal was recorded and reviewed to ensure that the mice did not employ nonspatial/kinesthetic strategies (that is, chaining) to solve the task. No chaining response (defined as a mouse consecutively entering three (or more) adjacent arms to solve the task) was observed for either genotype.

\section{Novel object recognition}

This task of recognition memory utilizes the fact that animals will spend more time exploring a novel object compared with an object that they are familiar with in order to satisfy their innate curiosity/exploratory instinct. The test apparatus consisted of an open field box measuring $39.4 \mathrm{~cm} \times 78.8 \mathrm{~cm}$ change confirmed. in diameter, and all sessions were video-recorded. On day 1 the animal was allowed to explore the open field box for a 15-minute time period. The following day the animals were each exposed to a 10-minute information session (that is, the A/A session with identical objects present). This information session was followed by a 1-hour delay during which the animals were returned to their home cages. After the delay the animals performed a 10-minute dissimilar stimuli session (A/B). The objects were made of hard plastic and had previously been counterbalanced to control for any object preference bias. The total amount of time spent with each object was recorded and scored using fully automated EthoVision XT 8.0 video tracking software (Noldus Information Technology).

The time spent was operationally defined as occurring when an animal directed its nose to the object at a distance $<2.0 \mathrm{~cm}$ and/or by the animal touching the object with its nose or mouth. Data are presented as the $D^{2}$ discrimination index. The $D^{2}$ index is a common measure of discrimination between novel and familiar objects, and is considered one of the most reliable measures of discrimination because it corrects for total exploratory activity of each animal [29]. The $D^{2}$ index is calculated for an A/B session by examining the difference in time spent exploring the novel and familiar objects divided by the total exploration time for both objects:

$$
D^{2}=(\text { novel }- \text { familiar }) /(\text { novel }+ \text { familiar })
$$

The $D^{2}$ index thus corrects for total exploratory behavior of each mouse.

\section{Statistical analysis}

All statistical analyses were performed using GraphPad Prism Version 5.00 (GraphPad Software, San Diego, CA, USA). In the cross-sectional study design, experimental groups consisted of two genotypes at four different ages: 7 months, 11 months, 15 months, and 24 months. Each group used a $\sim 50: 50$ ratio of males to females. The number of mice used per group was 5 to 12 mice per group. Unless otherwise indicated, for WT mice there were 10 aged 7 months, nine aged 11 months, five aged 15 months, and 10 aged 24 months; and for KI mice, there were nine aged 7 months, five aged 11 months, 10 aged 15 months, and five aged 24 months.

Comparison between individual experimental groups was performed by unpaired $t$ test where appropriate. Regression analysis for RAWM and novel object recognition (NOR) cognitive data was modeled via linear regression in GraphPad with genotype, age, and errors/ $D^{2}$ index as independent variables and using a 95\% confidence interval. Data are expressed as the mean \pm the standard error of the mean. Differences between means from experimental groups were considered significant at the $P<0.05$ level.

\section{Results}

\section{Vestibulomotor behavior}

The vestibulomotor behavior of APP/PS1 KI and WT control mice is presented in Figure 1. As shown in Figure 1A, no differences were observed between APP/ PS1 KI and WT mice in grip strength performance. Further, the grip strength remained consistent across the age groups for both APP/PS1 KI mice and their WT counterparts.

No differences in beam walk performance were observed between genotypes or for any age group of mouse tested (Figure 1B). The number of foot slips for both APP/PS1 KI and WT mice increased as the size of the bar decreased. APP/PS1 KI mice made $1.92 \pm 0.26$ foot slips compared with $1.46 \pm 0.37$ foot slips for the WT mice crossing the $3 \mathrm{~cm}$ beam. For the $2 \mathrm{~cm}$ beam, the APP/PS1 KI mice made $9.69 \pm 1.09$ foot slips while the WT mice made $8.36 \pm 0.70$ foot slips. Figure $1 \mathrm{~B}$ also shows the APP/PS1 KI and WT mice performance on the $1 \mathrm{~cm}$ beam (APP/PS1 KI mice had 20.28 \pm 1.54 foot slips compared with $17.92 \pm 1.00$ foot slips for WT mice).

The open field behavioral task to assess ambulatory movement showed no difference between APP/PS1 KI and WT mice in distance traveled (Figure 1C) or in movement speed (Figure 1D) for any age group. Similarly, no differences in habituation behavior were observed in the open field task for either genotype or for any age group (data not shown).

Finally, no differences were observed at any age group between APP/PS1 KI and WT mice in rotor rod performance (Figure 1E), although the younger animals (7 months old) performed this task somewhat better than the older age groups. Interestingly, performance was negatively correlated with the weight of the animals 

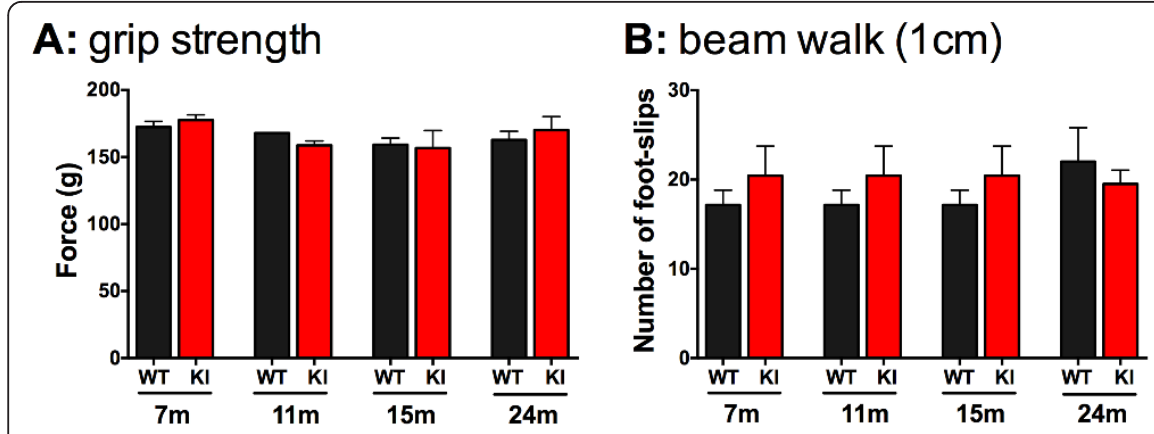

\section{E: rotor-rod}

\section{C: open field (distance)}

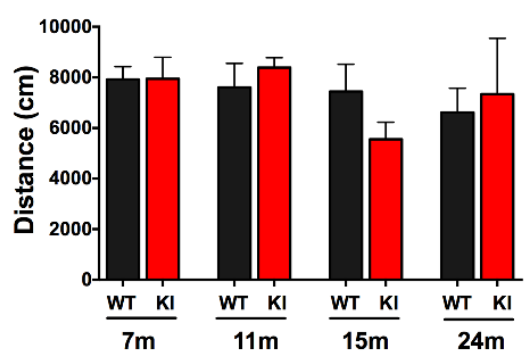

\section{D: open field (velocity)}
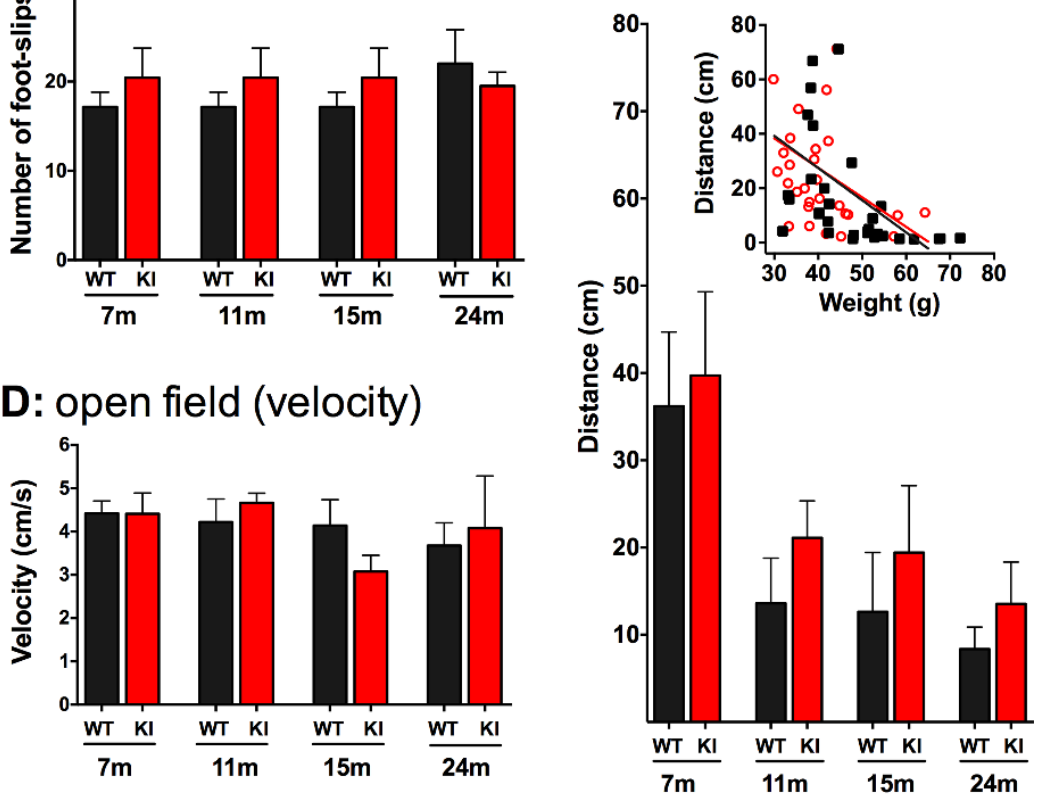

wild type

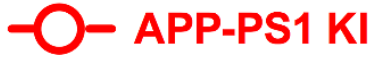

Figure 1 Motor behavior of APP/PS1 KI and wild-type control mice. (A) No differences in grip strength are observed between amyloid precursor protein/presenilin-1 knock-in (APP/PS1 KI) mice and their wild-type (WT) counterparts in any age group. (B) No performance differences are observed between APP/PS1 KI and WT mice for any age group in the beam walk task. (C), (D) Open field performance shows no significant differences in ambulatory movement, as assessed by (C) distance traveled or(D) movement velocity, between APP/PS1 KI and WT mice for any age group. (E) Rotor rod performance shows no differences between APP/PS1 KI and WT mice for any age group. However, performance is negatively correlated with weight (E insert) for the WT animals $(P=0.004)$ and is almost significantly correlated for APP/PS1 KI mice performance $(P=0.052)$. Number of mice: $10 \mathrm{WT}$ and nine Kl mice aged 7 months; five WT and eight KI mice aged 11 months; eight WT and eight KI mice aged 15 months; and eight WT and five KI mice aged 24 months.

(Figure 1E, insert). Specifically, WT mice performance showed a highly significant negative correlation with weight $(P=0.004)$, and APP/PS1 KI mice showed a similar pattern that did not reach statistical significance $(P=0.052)$.

\section{Anxiety-related behavior}

The anxiety-related behavior of APP/PS1 KI and WT mice was assessed by two behavioral tests: analysis of time spent in the center zone versus peripheral zone of the open field arena; and the elevated plus maze task. As shown in Figure 2A, no differences were seen between APP/PS1 KI and WT mice, or between any age group of mice, in the amount of time each mouse spent in the open center zone of the open field behavioral task. Similarly, in the elevated plus maze task, both the APP/PS1 KI and WT mice spent more time in the enclosed arms compared with the open arms, and this was consistent across all age groups (Figure 2B). No significant differences were observed between APP/PS1 KI and WT mice at any age.

\section{Cognitive behavior}

The cognitive behavior of APP/PS1 KI and WT mice was tested in the RAWM and NOR behavioral tasks tests that measure spatial reference memory and recognition memory, respectively.

In the RAWM, there was no difference in performance between APP/PS1 KI mice and WT mice at 7 months of age (Figure $3 \mathrm{~A}$ ). In contrast, APP/PS1 KI mice aged 11 months old (Figure 3B), 15 months old (Figure 3C), and 24 months old (Figure 3D) performed significantly worse in the RAWM task than did the WT mice of the same ages. When the RAWM maze data are analyzed as a function of errors made versus age of the animals (Figure 3E), it is evident that APP/PS1 KI mice progressively increase the number of errors they make as they age (and the disease progresses).

In the NOR behavior task, the APP/PS1 KI and WT mice both showed a clear preference for novel object exploration during the dissimilar stimuli (A/B) session compared with the familiar at the ages of 7 and 11 months old (Figure 3F). However, in the groups of 15 and 


\section{A: open field (time in center)}

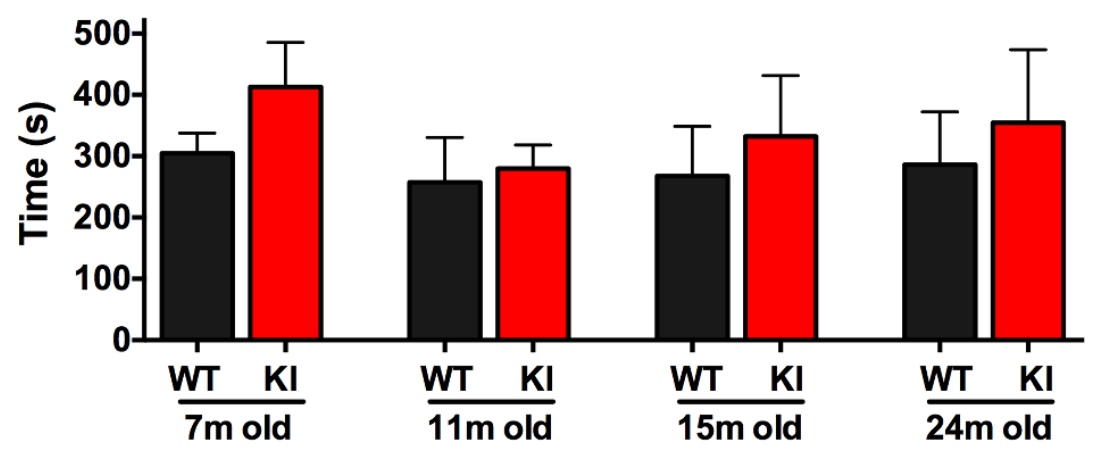

\section{B: elevated plus maze}

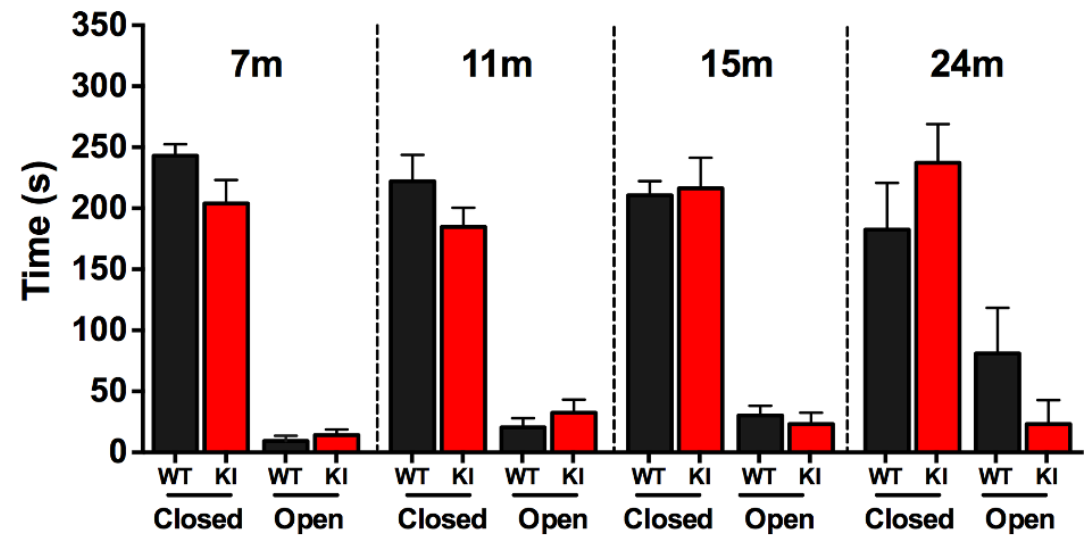

\section{wild type APP-PS1 KI}

Figure 2 Anxiety-related behavior of APP/PS1 KI and wild-type control mice. (A) No difference in the time spent exploring in the center zone between the amyloid precursor protein/presenilin-1 knock-in (APP/PS1 KI) mice and the wild-type (WT) mice was observed in any age group. (B) Elevated plus maze anxiety behavior is also similar between APP/PS1 KI and WT mice for all ages. Number of mice: $10 \mathrm{WT}$ and nine KI mice aged 7 months; five WT and eight KI mice aged 11 months; eight WT and eight KI mice aged 15 months; and eight WT and five KI mice aged 24 months.

24 month olds, the APP/PS1 KI mice lost the ability to discriminate between familiar and novel objects and were significantly impaired compared with the WT controls ( $P=0.044$ for 15 month olds, $P=0.041$ for 24 month olds). Each animal tested had an exploration time $>10$ seconds with each object, and no significant difference in movement speed (velocity range: 2.4 to $3.6 \mathrm{~cm} /$ second) was observed between genotypes or age groups. When the NOR task data are analyzed as a function of the $D^{2}$ recognition index versus age of the animals (Figure 3G), it is evident that APP/PS1 KI mice also become progressively impaired in this task as they age and the AD-relevant pathology progresses.

\section{Discussion}

Many lines of genetically altered mice have been generated during the past few decades in an effort to better understand the pathogenesis of AD. These mouse models of $\mathrm{AD}$ pathobiology have provided significant neuropathological, biochemical, physiological, and behavioral insights into AD pathogenesis. Many of the AD mouse models differ in the site of the mutation in APP, or in the number of APP 


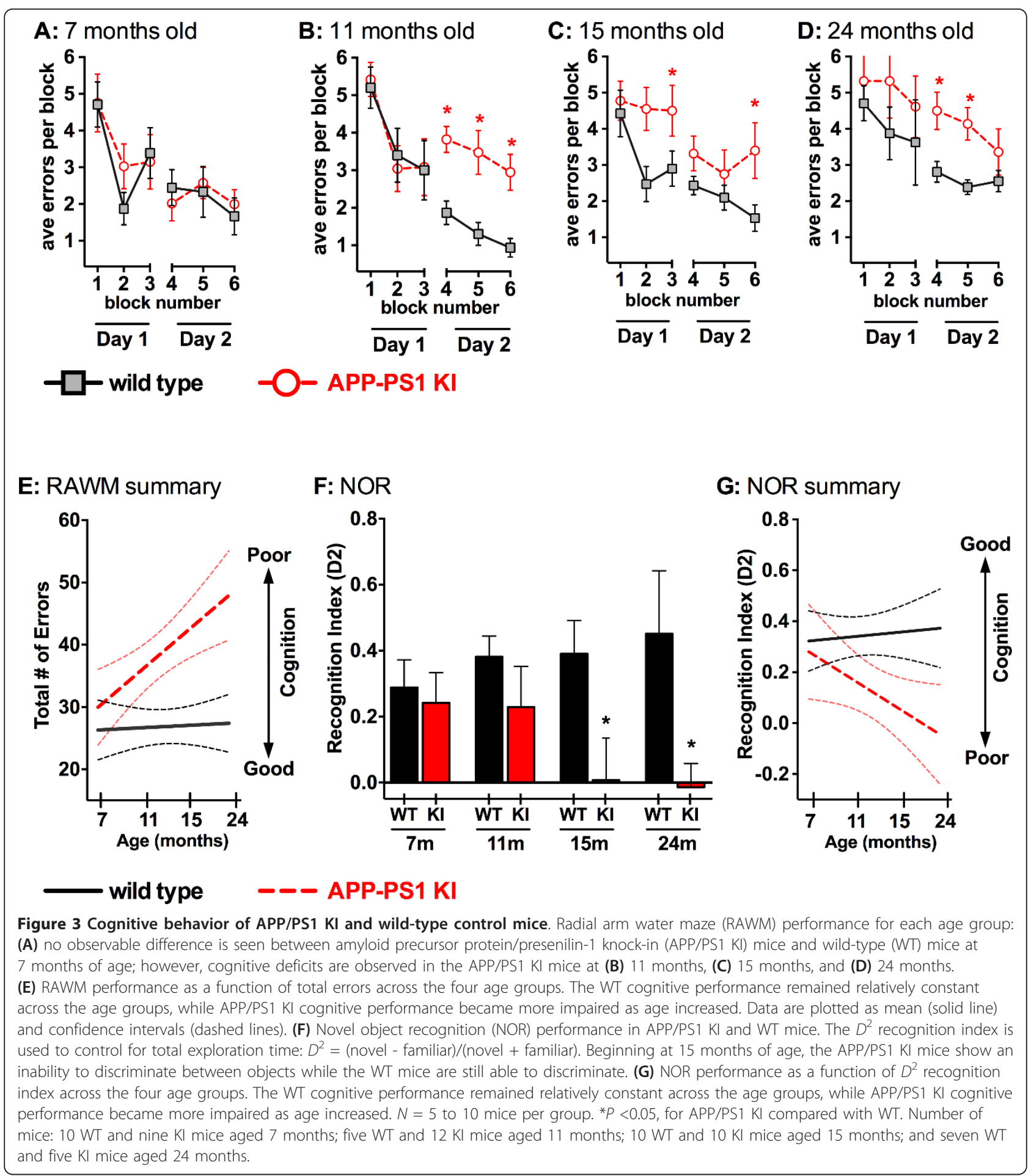

mutations in one mouse, or the addition of mutations in PS1 or tau. In general, the genetic differences result in each mouse model having a unique pathobiology that makes it acutely useful for preclinical testing of a particular type of AD-relevant therapeutics. For example, if the mechanism of action of a specific preclinical therapeutic is to decrease cytokine overproduction, then a mouse model that demonstrates cytokine overproduction is needed for accurate testing of the therapeutic.

Improvements in behavioral endpoints are often the gold standard used to demonstrate efficacy of preclinical therapeutics. However, for such endpoints to be useful, 
it is necessary to know when cognitive deficits reproducibly develop in the AD mouse model in relation to the particular druggable target of interest. As shown in Figure 4, the temporal time courses can be quite different between commonly used models. In addition, some behavioral tasks are clearly more sensitive to cognitive deficit detection at earlier ages. Figure 4 also shows how noncognitive behaviors, such as increased activity in motor tasks, should be considered in the selection of the most appropriate preclinical model to use for a particular study, because these noncognitive behaviors may interfere with the interpretation of cognitive tasks.

To assess the onset and progression of the cognitive impairments in the APP/PS1 KI mouse model, we have performed a comprehensive behavioral analysis across the lifespan of this model from 7 to 24 months old. Our data document clear age-dependent cognitive deficits in the APP/PS1 KI mice in both recognition memory (NOR) and spatial reference memory (RAWM) that become more prominent with increasing age. Further, in Figure 4 we compare the APP/PS1 KI mouse model with other $\mathrm{AD}$ mouse models in regard to the onset/ progression of $\mathrm{AD}$-relevant impairments in motor function, anxiety-related behavior, and cognition in an attempt to clarify how the APP/PS1 KI model fits into the growing literature on modeling $\mathrm{AD}$ in rodents. The data presented here for motor function, anxiety-related behavior, and cognitive deficits are critically important to the future application and utility of this model in preclinical testing of AD-relevant therapeutics by: establishing baseline behavioral characteristics of this model; and providing valuable information helpful in appropriate study design. These are important observations, as they establish baseline motor function and anxiety behavior, which is important to know in any mouse model prior to assessing cognitive functioning to avoid unwanted confounds [30,31].

In contrast to a number of the mice strains shown in Figure 4, which were found to have motor impairment and hyperactivity, the APP/PS1 KI mice exhibit no differences in ambulatory movement, grip strength, or coordination when compared with WT controls at any of the ages tested. There were also no anxiety-related behavior deficits seen at any age in the APP/PS1 KI mice in the elevated plus maze tasks. This is in contrast to the Tg2576, J20, APP/PS1, and 5xFAD mice, which all were found to have increased anxiety-related behavior in the elevated plus maze task. In the open field task, animals with elevated anxiety levels will spend little time exploring the center of the chamber [30,32]. The APP/PS1 KI mice do not exhibit anxiety-related behavior, as they showed normal exploration of the center of the open field chamber. Anxiety behavior did not differ between APP/PS1 KI mice and WT mice for any age tested. Our results therefore demonstrate that there are no deficits in either motor function or anxiety levels that could potentially confound cognitive testing in this mouse model of $\mathrm{AD}$, which is dissimilar to the majority of the mouse models shown in Figure 4.

Attempts to model AD-relevant cognitive deficits in mouse models have met with some degree of success $[33,34]$. Reference memory is a type of memory that is often assessed in various mouse models of AD because deficits in this type of memory are highly specific for hippocampal function (one of the earliest/most severely affected brain regions in human AD) [35]. One common method for assessing deficits in hippocampal-based reference memory is through the use of explorationbased memory tasks such as the Morris water maze and the RAWM [33]. Here we observe deficits in spatial reference memory for the APP/PS1 KI mice when tested in the RAWM. These deficits in spatial reference memory are first evident in the 11 month age group, and continue to progress as the age/pathology increases in this model. The temporal onset and progression of cognitive impairment compared with other commonly used AD mouse models can be seen in Figure 4. For example, compared with other APP and PS1 AD mouse models, such as the APP/PS1 model and the APP + PS1 model, the onset of cognitive deficits in the APP/PS1 KI model appears to occur slightly later in life. Both the APP + PS1 model and the APP/PS1 model show deficits at 4 to 6 months of age [36-39], whereas the APP/PS1 KI mice show deficits starting at 11 months old (Figure 3).

Another commonly tested type of AD-relevant memory is that of recognition memory. The most common way to assess recognition memory in mice is through the use of the NOR task [33]. Here we see cognitive impairment in the NOR task manifest in the APP/PS1 KI model at 15 months of age. As shown in Figure 4, this temporal pattern is similar to the onset of NOR deficits in some other AD mouse models, such as the Tg2576 mice and the APP + PS1 model. In contrast, some mouse models such as the PDAPP, APP23, TgCRND8, J20, 5xFAD, and 3xTG-AD mice show impairment in recognition memory at a younger age. Overall, for many of the AD mouse models it appears that deficits in spatial working memory (Morris water maze and RAWM) become apparent earlier than deficits in recognition memory (NOR).

With regard to $\beta$-amyloid, similar to other commonly used models of AD such as the Tg2576 mouse and the $5 x F A D$ mouse, in the APP/PS1 KI model the amyloid burden occurs prior to the onset of cognitive deficits [40-43]. Other potential therapeutic targets such as elevated levels of oxidative stress and neuroinflammation also occur before the observable cognitive deficits in the APP/PS1 KI mouse model $[12,14,17,44]$. With respect to 


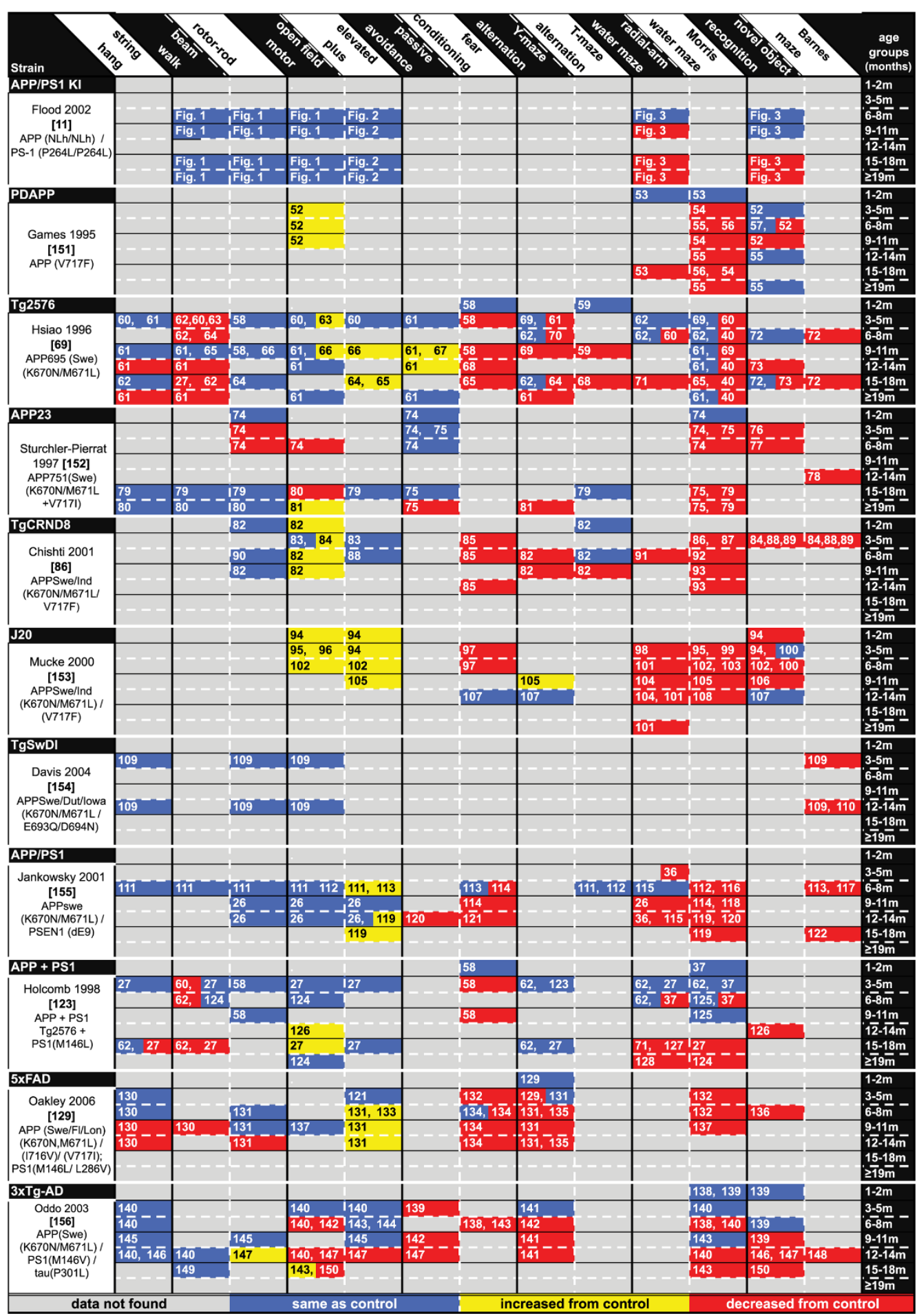

Figure 4 Comparison of behavior changes in APP/PS1 KI mice with other common Alzheimer's disease mouse models. Data analysis from the literature focused on a compilation of the most widely used behavioral tasks to assess the onset/progression of motor function impairment, anxiety-related behavior, and cognitive impairment. Blue data, the Alzheimer's disease (AD) mouse performed the same as the wildtype (WT) control; yellow data, the AD mouse was increased from control; red data, the AD mouse was decreased from control. The numbers within the data boxes refer to the literature citation. APP/PS1 Kl, amyloid precursor protein/presenilin-1 knock-in. 
oxidative stress, the APP/PS1 KI mouse model is also considerably different from other models such as the Tg2576 and 3xTG-AD mice in the magnitude and temporal time course of oxidative stress [15,44-48]. Elevated levels of oxidative stress have been linked to the cognitive deficits seen in AD [49,50]. In a study of the APP/ PS1 KI mice [18], NADPH oxidase (a marker of oxidative stress) was reported to increase with the age of the animal and correlate with increased $\beta$-amyloid levels. Further, this same study reported that NADPH oxidase is correlated with APP/PS1 KI behavioral performance in the Stone T-maze, with lower levels of NADPH oxidase and slight deficits observable at 4 to 6 months of age and both becoming more pronounced by 16 to 19 months of age [18]. This provides an example of how the APP/PS1 KI mouse could be a useful model to test preclinical therapeutics targeted at reducing oxidative stress.

$\mathrm{AD}$ is a very complex disease, with many interrelated mechanisms and pathologies occurring concomitantly. Although no animal model fully replicates the human disease, AD mouse models are useful to investigate different aspects of AD pathology and disease progression. AD mouse models have been invaluable in advancing our understanding of disease mechanisms and in preclinical testing of potential therapeutics. Paramount to the selection of the appropriate model for evaluation of potential therapeutic interventions is demonstration that the desired relevant target for the preclinical therapeutic is present in the model at a therapeutically relevant time. For example, the APP/PS1 KI model used here is an ideal model for assessing the pathogenesis and effects of early oxidative stress or dysregulated neuroinflammation as we recently showed [17]. In contrast, the APP/ PS1 KI model lacks AD-relevant tau pathology. This model would therefore be inappropriate to examine topics relating to the effect of microtubule-associated tau disruption in AD. Instead, a model such as the 3xTG-AD mouse (or another relevant model showing tau pathology) should be selected instead. Similarly, if AD-related motor deficits [51] are the target of research interest, selection of an appropriate model (Figure 4) showing motor deficits such as the Tg2576 or 5xFAD mouse would be salient, whereas a model like the APP/ PS1 KI model that does not develop motor deficits would not be useful. Conversely, if AD-related cognitive deficits are of interest, then motor deficits need to be accounted for, or else a model that lacks motor deficits but that displays cognitive impairment should be selected so as to eliminate possible motor related confounds [31].

Each transgenic mouse model of AD provides different insights into aspects of AD pathology and progression. Careful forethought is therefore required in the selection of an optimal model based on specific research interests.
Our hope is that, with regard to motor and cognitive deficits relating to $\mathrm{AD}$, the discussion and Figure 4 presented here can help in the selection of the ideal model by providing an overview of the development and time course of behavioral deficits in the commonly used mouse models of $\mathrm{AD}$.

\section{Conclusion}

This study is the first comprehensive behavioral analysis reported for the APP/PS1 KI mouse model of AD and the results presented here add to a growing literature for this model. The lack of any motor/coordination deficits or abnormal anxiety levels, coupled with an age/disease-related cognitive decline and the high physiological relevance of this model, make it well suited for utilization in preclinical testing of AD-relevant therapeutics.

\section{Abbreviations}

AD: Alzheimer's disease; APP: amyloid precursor protein; $D^{2}$ : discrimination index; Kl: knock-in; NADPH: nicotinamide adenine dinucleotide phosphate; NOR: novel object recognition; PS-1: presenilin-1; RAWM: radial arm water maze; WT: wild type

\section{Authors' contributions}

SJW participated in the design of the research studies, performed the behavioral tests, and drafted the manuscript. ADB participated in the design of the study, performed the statistical analyses, and helped analyze data and draft the manuscript. LJVE conceived of the study, participated in its design and coordination, and helped write the manuscript. All authors read and approved the final manuscript.

\section{Competing interests}

The authors declare that they have no competing interests.

\section{Acknowledgements}

The authors thank Danielle Goulding for maintenance of the mouse colonies and excellent technical assistance. This research was supported in part by National Institutes of Health grants R01 NS064247 (LJVE), P01 AG005119 (LJVE), and F32 AG037280 (ADB), and by the Edward N. \& Della L. Thome Memorial Foundation Awards Program in Alzheimer's Disease Drug Discovery Research (LJVE).

\section{Author details}

'Sanders-Brown Center on Aging, 800 S. Limestone, University of Kentucky, Lexington, KY 40536, USA. ${ }^{2}$ Department of Anatomy and Neurobiology, 800 S. Limestone, University of Kentucky, Lexington, KY 40536, USA.

Received: 19 March 2013 Revised: 29 April 2013

Accepted: 24 May 2013 Published: 24 May 2013

\section{References}

1. Elder GA, Gama Sosa MA, De Gasperi R: Transgenic mouse models of Alzheimer's disease. Mt Sinai J Med 2010, 77:69-81.

2. Auffret A, Gautheron V, Repici M, Kraftsik R, Mount HT, Mariani J, Rovira C: Age-dependent impairment of spine morphology and synaptic plasticity in hippocampal CA1 neurons of a presenilin 1 transgenic mouse model of Alzheimer's disease. J Neurosci 2009, 29:10144-10152.

3. Malthankar-Phatak G, Poplawski S, Toraskar N, Siman R: Combination therapy prevents amyloid-dependent and -independent structural changes. Neurobiol Aging 2012, 33:1273-1283.

4. Mucke L, Masliah E, Johnson WB, Ruppe MD, Alford M, Rockenstein EM, Forss-Petter S, Pietropaolo M, Mallory M, Abraham CR: Synaptotrophic effects of human amyloid beta protein precursors in the cortex of transgenic mice. Brain Res 1994, 666:151-167. 
5. Nalbantoglu J, Tirado-Santiago G, Lahsaini A, Poirier J, Goncalves O, Verge G, Momoli F, Welner SA, Massicotte G, Julien JP, Shapiro ML: Impaired learning and LTP in mice expressing the carboxy terminus of the Alzheimer amyloid precursor protein. Nature 1997, 387:500-505.

6. Thinakaran G, Borchelt DR, Lee MK, Slunt HH, Spitzer L, Kim G, Ratovitsky T, Davenport F, Nordstedt C, Seeger M, Hardy J, Levey Al, Gandy SE, Jenkins NA, Copeland NG, Price DL, Sisodia SS: Endoproteolysis of presenilin 1 and accumulation of processed derivatives in vivo. Neuron 1996, 17:181-190.

7. Wen PH, Shao X, Shao Z, Hof PR, Wisniewski T, Kelley K, Friedrich VL, Ho L $J r$, Pasinetti GM, Shioi J, Robakis NK, Elder GA: Overexpression of wild type but not an FAD mutant presenilin-1 promotes neurogenesis in the hippocampus of adult mice. Neurobiol Dis 2002, 10:8-19.

8. Reaume AG, Howland DS, Trusko SP, Savage MJ, Lang DM, Greenberg BD, Siman R, Scott RW: Enhanced amyloidogenic processing of the betaamyloid precursor protein in gene-targeted mice bearing the Swedish familial Alzheimer's disease mutations and a 'humanized' $A \beta$ sequence. J Biol Chem 1996, 271:23380-23388.

9. Siman R, Reaume AG, Savage MJ, Trusko S, Lin YG, Scott RW, Flood DG: Presenilin-1 P264L knock-in mutation: differential effects on a $\beta$ production, amyloid deposition, and neuronal vulnerability. J Neurosci 2000, 20:8717-8726.

10. Siman R, Flood DG, Thinakaran G, Neumar RW: Endoplasmic reticulum stress-induced cysteine protease activation in cortical neurons: effect of an Alzheimer's disease-linked presenilin-1 knock-in mutation. J Biol Chem 2001, 276:44736-44743

11. Flood DG, Reaume AG, Dorfman KS, Lin YG, Lang DM, Trusko SP, Savage MJ, Annaert WG, De Strooper B, Siman R, Scott RW: FAD mutant PS-1 gene-targeted mice: increased $A \beta 42$ and $A \beta$ deposition without APP overproduction. Neurobiol Aging 2002, 23:335-348

12. Murphy MP, Beckett TL, Ding Q, Patel E, Markesbery WR, St Clair DK, LeVine $H$, Keller $J N$ : $A \beta$ solubility and deposition during AD progression and in APPxPS-1 knock-in mice. Neurobiol Dis 2007, 27:301-311.

13. Siman R, Salidas S: Gamma-secretase subunit composition and distribution in the presenilin wild-type and mutant mouse brain. Neuroscience 2004, 129:615-628.

14. Zhang C, McNeil E, Dressler L, Siman R: Long-lasting impairment in hippocampal neurogenesis associated with amyloid deposition in a knock-in mouse model of familial Alzheimer's disease. Exp Neurol 2007, 204:77-87.

15. Studzinski CM, Li F, Bruce-Keller AJ, Fernandez-Kim SO, Zhang L, Weidner AM, Markesbery WR, Murphy MP, Keller JN: Effects of short-term western diet on cerebral oxidative stress and diabetes related factors in APP $\times$ PS1 knock-in mice. J Neurochem 2009, 108:860-866

16. Thibault $O$, Pancani $T$, Landfield PW, Norris CM: Reduction in neuronal L-type calcium channel activity in a double knock-in mouse model of Alzheimer's disease. Biochim Biophys Acta 2012, 1822:546-549.

17. Bachstetter AD, Norris CM, Sompol P, Wilcock DM, Goulding D, Neltner JH St Clair D, Watterson DM, Van Eldik L: Early stage drug treatment that normalizes proinflammatory cytokine production attenuates synaptic dysfunction in a mouse model that exhibits age-dependent progression of Alzheimer's disease-related pathology. J Neurosci 2012, 32:10201-10210.

18. Bruce-Keller AJ, Gupta S, Knight AG, Beckett TL, McMullen JM, Davis PR, Murphy MP, Van Eldik LJ, St Clair D, Keller JN: Cognitive impairment in humanized APP $\times$ PS1 mice is linked to $A \beta(1-42)$ and NOX activation. Neurobiol Dis 2011, 44:317-326.

19. Zhang $R$, Xue G, Wang S, Zhang L, Shi C, Xie X: Novel object recognition as a facile behavior test for evaluating drug effects in ABPP/PS1 Alzheimer's disease mouse model. J Alzheimers Dis 2012, 31:801-812.

20. Barker GR, Warburton EC: When is the hippocampus involved in recognition memory? J Neurosci 2011, 31:10721-10731.

21. Diamond DM, Park CR, Heman KL, Rose GM: Exposing rats to a predator impairs spatial working memory in the radial arm water maze. Hippocampus 1999, 9:542-552.

22. Anantharaman M, Tangpong J, Keller JN, Murphy MP, Markesbery WR Kiningham KK, St Clair DK: Beta-amyloid mediated nitration of manganese superoxide dismutase: implication for oxidative stress in a APPNLH/NLH $\times$ PS-1P264L/P264L double knock-in mouse model of Alzheimer's disease. Am J Pathol 2006, 168:1608-1618

23. Tsenter J, Beni-Adani L, Assaf $Y$, Alexandrovich AG, Trembovler $V$, Shohami E: Dynamic changes in the recovery after traumatic brain injury in mice: effect of injury severity on T2-weighted MRI abnormalities, and motor and cognitive functions. J Neurotrauma 2008, 25:324-333.

24. Liu X, Wu R, Tai F, Ma L, Wei B, Yang X, Zhang X, Jia R: Effects of group housing on stress induced emotional and neuroendocrine alterations. Brain Res 2013, 1502:71-80.

25. Prut $L$, Belzung $C$ : The open field as a paradigm to measure the effects of drugs on anxiety-like behaviors: a review. Eur J Pharmacol 2003, 463:3-33.

26. Sood A, Warren Beach J, Webster SJ, Terry AV, Buccafusco JJ: The effects of JWB1-84-1 on memory-related task performance by amyloid A $\beta$ transgenic mice and by young and aged monkeys. Neuropharmacology 2007, 53:588-600.

27. Arendash GW, King DL, Gordon MN, Morgan D, Hatcher JM, Hope CE, Diamond DM: Progressive, age-related behavioral impairments in transgenic mice carrying both mutant amyloid precursor protein and presenilin-1 transgenes. Brain Res 2001, 891:42-53.

28. Alamed J, Wilcock DM, Diamond DM, Gordon MN, Morgan D: Two-day radial-arm water maze learning and memory task; robust resolution of amyloid-related memory deficits in transgenic mice. Nat Protoc 2006, 1:1671-1679.

29. Sik A, van Nieuwehuyzen P, Prickaerts J, Blokland A: Performance of different mouse strains in an object recognition task. Behav Brain Res 2003, 147:49-54.

30. Rodriguiz RM, Wetsel WC: Assessments of cognitive deficits in mutant mice. In Animal Models of Cognitive Impairment. Edited by: Levin ED, Buccafusco JJ. Boca Raton, FL; 2006:

31. Crawley JN: Behavioral phenotyping strategies for mutant mice. Neuron 2008, 57:809-818.

32. Kliethermes $\mathrm{CL}$, Cronise K, Crabbe JC: Anxiety-like behavior in mice in two apparatuses during withdrawal from chronic ethanol vapor inhalation. Alcohol Clin Exp Res 2004, 28:1012-1019.

33. Bryan KJ, Lee H, Perry G, Smith MA, Casadesus G: Transgenic mouse models of Alzheimer's disease: behavioral testing and considerations. In Methods of Behavior Analysis in Neuroscience Edited by: Buccafusco JJ. Boca Raton, FL, 2 2009.

34. Kobayashi DT, Chen KS: Behavioral phenotypes of amyloid-based genetically modified mouse models of Alzheimer's disease. Genes Brain Behav 2005, 4:173-196.

35. West MJ: Regionally specific loss of neurons in the aging human hippocampus. Neurobiol Aging 1993, 14:287-293.

36. Park JH, Widi GA, Gimbel DA, Harel NY, Lee DH, Strittmatter SM: Subcutaneous Nogo receptor removes brain amyloid-beta and improves spatial memory in Alzheimer's transgenic mice. J Neurosci 2006, 26:13279-13286.

37. Trinchese F, Liu S, Battaglia F, Walter S, Mathews PM, Arancio O: Progressive age-related development of Alzheimer-like pathology in APP/PS1 mice. Ann Neurol 2004, 55:801-814.

38. McKenna JT, Christie MA, Jeffrey BA, McCoy JG, Lee E, Connolly NP, Ward CP, Strecker RE: Chronic ramelteon treatment in a mouse model of Alzheimer's disease. Arch Ital Biol 2012, 150:5-14.

39. Nagakura A, Shitaka Y, Yarimizu J, Matsuoka N: Characterization of cognitive deficits in a transgenic mouse model of Alzheimer's disease and effects of donepezil and memantine. Eur J Pharmacol 2013, 703:53-61.

40. Westerman MA, Cooper-Blacketer D, Mariash A, Kotilinek L, Kawarabayashi T, Younkin LH, Carlson GA, Younkin SG, Ashe KH: The relationship between $A \beta$ and memory in the Tg2576 mouse model of Alzheimer's disease. J Neurosci 2002, 22:1858-1867.

41. Hall AM, Roberson ED: Mouse models of Alzheimer's disease. Brain Res Bull 2012, 88:3-12.

42. Kimura R, Ohno M: Impairments in remote memory stabilization precede hippocampal synaptic and cognitive failures in 5XFAD Alzheimer mouse model. Neurobiol Dis 2009, 33:229-235.

43. Ohno M, Cole SL, Yasvoina M, Zhao J, Citron M, Berry R, Disterhoft JF, Vassar R: BACE1 gene deletion prevents neuron loss and memory deficits in 5XFAD APP/PS1 transgenic mice. Neurobiol Dis 2007, 26:134-145.

44. Abdul HM, Sultana R, St Clair DK, Markesbery WR, Butterfield DA: Oxidative damage in brain from human mutant APP/PS-1 double knock-in mice as a function of age. Free Radic Biol Med 2008, 45:1420-1425.

45. Pratico D, Uryu K, Leight S, Trojanoswki JQ, Lee VM: Increased lipid peroxidation precedes amyloid plaque formation in an animal model of Alzheimer amyloidosis. J Neurosci 2001, 21:4183-4187. 
46. Smith MA, Hirai K, Hsiao K, Pappolla MA, Harris PL, Siedlak SL, Tabaton M, Perry G: Amyloid-beta deposition in Alzheimer transgenic mice is associated with oxidative stress. J Neurochem 1998, 70:2212-2215.

47. Bader Lange ML, St Clair D, Markesbery WR, Studzinski CM, Murphy MP, Butterfield DA: Age-related loss of phospholipid asymmetry in APP(NLh)/ APP(NLh) $\times$ PS-1(P264L)/PS-1(P264L) human double mutant knock-in mice: relevance to Alzheimer disease. Neurobiol Dis 2010, 38:104-115.

48. Yao J, Irwin RW, Zhao L, Nilsen J, Hamilton RT, Brinton RD: Mitochondrial bioenergetic deficit precedes Alzheimer's pathology in female mouse model of Alzheimer's disease. Proc Natl Acad Sci USA 2009, 106:14670-14675.

49. Kim HA, Miller AA, Drummond GR, Thrift AG, Arumugam TV, Phan TG, Srikanth VK, Sobey CG: Vascular cognitive impairment and Alzheimer's disease: role of cerebral hypoperfusion and oxidative stress. Naunyn Schmiedebergs Arch Pharmacol 2012, 385:953-959.

50. Feng Y, Wang X: Antioxidant therapies for Alzheimer's disease. Oxid Med Cell Longev 2012, 2012:472932.

51. Scarmeas N, Hadjigeorgiou GM, Papadimitriou A, Dubois B, Sarazin M, Brandt J, Albert M, Marder K, Bell K, Honig LS, Wegesin D, Stern Y: Motor signs during the course of Alzheimer disease. Neurology 2004, 63:975-982.

52. Dodart JC, Meziane H, Mathis C, Bales KR, Paul SM, Ungerer A: Behavioral disturbances in transgenic mice overexpressing the V717F beta-amyloid precursor protein. Behav Neurosci 1999, 113:982-990.

53. Nilsson LN, Arendash GW, Leighty RE, Costa DA, Low MA, Garcia MF, Cracciolo JR, Rojiani A, Wu X, Bales KR, Paul SM, Potter H: Cognitive impairment in PDAPP mice depends on ApoE and ACT-catalyzed amyloid formation. Neurobiol Aging 2004, 25:1153-1167.

54. Hartman RE, Izumi Y, Bales KR, Paul SM, Wozniak DF, Holtzman DM: Treatment with an amyloid-beta antibody ameliorates plaque load, learning deficits, and hippocampal long-term potentiation in a mouse model of Alzheimer's disease. J Neurosci 2005, 25:6213-6220.

55. Chen G, Chen KS, Knox J, Inglis J, Bernard A, Martin SJ, Justice A, McConlogue L, Games D, Freedman SB, Morris RG: A learning deficit related to age and beta-amyloid plaques in a mouse model of Alzheimer's disease. Nature 2000, 408:975-979.

56. Daumas S, Sandin J, Chen KS, Kobayashi D, Tulloch J, Martin SJ, Games D, Morris RG: Faster forgetting contributes to impaired spatial memory in the PDAPP mouse: deficit in memory retrieval associated with increased sensitivity to interference? Learn Mem 2008, 15:625-632.

57. Dodart JC, Bales KR, Gannon KS, Greene SJ, DeMattos RB, Mathis C, DeLong CA, Wu S, Wu X, Holtzman DM, Paul SM: Immunization reverses memory deficits without reducing brain $A \beta$ burden in Alzheimer's disease model. Nat Neurosci 2002, 5:452-457.

58. Dineley $K T$, Xia X, Bui D, Sweatt JD, Zheng $H$ : Accelerated plaque accumulation, associative learning deficits, and up-regulation of alpha 7 nicotinic receptor protein in transgenic mice co-expressing mutant human presenilin 1 and amyloid precursor proteins. J Biol Chem 2002, 277:22768-22780.

59. Chapman PF, White GL, Jones MW, Cooper-Blacketer D, Marshall VJ, Irizarry M, Younkin L, Good MA, Bliss TV, Hyman BT, Younkin SG, Hsiao KK: Impaired synaptic plasticity and learning in aged amyloid precursor protein transgenic mice. Nat Neurosci 1999, 2:271-276.

60. Arendash GW, Lewis J, Leighty RE, McGowan E, Cracchiolo JR, Hutton M, Garcia MF: Multi-metric behavioral comparison of APPsw and P301L models for Alzheimer's disease: linkage of poorer cognitive performance to tau pathology in forebrain. Brain Res 2004, 1012:29-41.

61. King DL, Arendash GW: Behavioral characterization of the $\operatorname{Tg} 2576$ transgenic model of Alzheimer's disease through 19 months. Physiol Behav 2002, 75:627-642.

62. Arendash GW, Gordon MN, Diamond DM, Austin LA, Hatcher JM, Jantzen P, DiCarlo G, Wilcock D, Morgan D: Behavioral assessment of Alzheimer's transgenic mice following long-term $A \beta$ vaccination: task specificity and correlations between $A \beta$ deposition and spatial memory. DNA Cell Biol 2001, 20:737-744.

63. King DL, Arendash GW, Crawford F, Sterk T, Menendez J, Mullan MJ: Progressive and gender-dependent cognitive impairment in the APP (SW) transgenic mouse model for Alzheimer's disease. Behav Brain Res 1999, 103:145-162.

64. Lalonde R, Lewis TL, Strazielle C, Kim H, Fukuchi K: Transgenic mice expressing the betaAPP695SWE mutation: effects on exploratory activity, anxiety, and motor coordination. Brain Res 2003, 977:38-45.
65. Lassalle JM, Halley H, Daumas S, Verret L, Frances B: Effects of the genetic background on cognitive performances of TG2576 mice. Behav Brain Res 2008, 191:104-110.

66. Gil-Bea FJ, Aisa B, Schliebs R, Ramirez MJ: Increase of locomotor activity underlying the behavioral disinhibition in tg2576 mice. Behav Neurosci 2007, 121:340-344

67. Ognibene E, Middei S, Daniele S, Adriani W, Ghirardi O, Caprioli A, Laviola G: Aspects of spatial memory and behavioral disinhibition in Tg2576 transgenic mice as a model of Alzheimer's disease. Behav Brain Res 2005 , 156:225-232

68. Corcoran KA, Lu Y, Turner RS, Maren S: Overexpression of hAPPswe impairs rewarded alternation and contextual fear conditioning in a transgenic mouse model of Alzheimer's disease. Learn Mem 2002, 9:243-252.

69. Hsiao K, Chapman P, Nilsen S, Eckman C, Harigaya Y, Younkin S, Yang F, Cole $\mathrm{G}$ : Correlative memory deficits, $\mathrm{A} \beta$ elevation, and amyloid plaques in transgenic mice. Science 1996, 274:99-102.

70. Ohno M, Sametsky EA, Younkin LH, Oakley H, Younkin SG, Citron M, Vassar R, Disterhoft JF: BACE1 deficiency rescues memory deficits and cholinergic dysfunction in a mouse model of Alzheimer's disease. Neuron 2004, 41:27-33.

71. Morgan D, Diamond DM, Gottschall PE, Ugen KE, Dickey C, Hardy J, Duff K, Jantzen P, DiCarlo G, Wilcock D, Connor K, Hatcher J, Hope C, Gordon M, Arendash GW: A beta peptide vaccination prevents memory loss in an animal model of Alzheimer's disease. Nature 2000, 408:982-985.

72. Yassine N, Lazaris A, Dorner-Ciossek C, Despres O, Meyer L, Maitre M, Mensah-Nyagan AG, Cassel JC, Mathis C: Detecting spatial memory deficits beyond blindness in tg2576 Alzheimer mice. Neurobiol Aging 2013, 34:716-730.

73. Oules B, Del Prete D, Greco B, Zhang X, Lauritzen I, Sevalle J, Moreno S, Paterlini-Brechot $P$, Trebak M, Checler F, Benfenati F, Chami M: Ryanodine receptor blockade reduces amyloid-beta load and memory impairments in Tg2576 mouse model of Alzheimer disease. J Neurosci 2012, 32:11820-11834.

74. Van Dam D, D'Hooge R, Staufenbiel M, Van Ginneken C, Van Meir F, De Deyn PP: Age-dependent cognitive decline in the APP23 model precedes amyloid deposition. Eur J Neurosci 2003, 17:388-396.

75. Kelly PH, Bondolfi L, Hunziker D, Schlecht HP, Carver K, Maguire E, Abramowski D, Wiederhold KH, Sturchler-Pierrat C, Jucker M, Bergmann R, Staufenbiel M, Sommer B: Progressive age-related impairment of cognitive behavior in APP23 transgenic mice. Neurobiol Aging 2003, 24:365-378.

76. Huang SM, Mouri A, Kokubo H, Nakajima R, Suemoto T, Higuchi M, Staufenbiel M, Noda Y, Yamaguchi H, Nabeshima T, Saido TC, Iwata N: Neprilysin-sensitive synapse-associated amyloid-beta peptide oligomers impair neuronal plasticity and cognitive function. J Biol Chem 2006, 281:17941-17951.

77. Heneka MT, Ramanathan M, Jacobs AH, Dumitrescu-Ozimek L, BilkeiGorzo A, Debeir T, Sastre M, Galldiks N, Zimmer A, Hoehn M, Heiss WD, Klockgether T, Staufenbiel M: Locus ceruleus degeneration promotes Alzheimer pathogenesis in amyloid precursor protein 23 transgenic mice. J Neurosci 2006, 26:1343-1354.

78. Prut L, Abramowski D, Krucker T, Levy CL, Roberts AJ, Staufenbiel M, Wiessner C: Aged APP23 mice show a delay in switching to the use of a strategy in the Barnes maze. Behav Brain Res 2007, 179:107-110.

79. Lalonde R, Dumont M, Staufenbiel M, Sturchler-Pierrat C, Strazielle C: Spatial learning, exploration, anxiety, and motor coordination in female APP23 transgenic mice with the Swedish mutation. Brain Res 2002, 956:36-44.

80. Lalonde R, Dumont M, Staufenbiel M, Strazielle C: Neurobehavioral characterization of APP23 transgenic mice with the SHIRPA primary screen. Behav Brain Res 2005, 157:91-98.

81. Dumont M, Strazielle C, Staufenbiel M, Lalonde R: Spatial learning and exploration of environmental stimuli in 24-month-old female APP23 transgenic mice with the Swedish mutation. Brain Res 2004, 1024:113-121.

82. Hyde LA, Kazdoba TM, Grilli M, Lozza G, Brusa R, Zhang Q, Wong GT, McCool MF, Zhang L, Parker EM, Higgins GA: Age-progressing cognitive impairments and neuropathology in transgenic CRND8 mice. Behav Brain Res 2005, 160:344-355

83. Touma C, Ambree O, Gortz N, Keyvani K, Lewejohann L, Palme R, Paulus W, Schwarze-Eicker K, Sachser N: Age- and sex-dependent development of adrenocortical hyperactivity in a transgenic mouse model of Alzheimer's disease. Neurobiol Aging 2004, 25:893-904 
84. Ambree O, Richter H, Sachser N, Lewejohann L, Dere E, de Souza Silva MA, Herring A, Keyvani K, Paulus W, Schabitz WR: Levodopa ameliorates learning and memory deficits in a murine model of Alzheimer's disease. Neurobiol Aging 2009, 30:1192-1204.

85. Hanna A, Iremonger K, Das P, Dickson D, Golde T, Janus C: Age-related increase in amyloid plaque burden is associated with impairment in conditioned fear memory in CRND8 mouse model of amyloidosis. Alzheimers Res Ther 2012, 4:21.

86. Chishti MA, Yang DS, Janus C, Phinney AL, Horne P, Pearson J, Strome R, Zuker N, Loukides J, French J, Turner S, Lozza G, Grilli M, Kunicki S, Morissette C, Paquette J, Gervais F, Bergeron C, Fraser PE, Carlson GA, George-Hyslop PS, Westaway D: Early-onset amyloid deposition and cognitive deficits in transgenic mice expressing a double mutant form of amyloid precursor protein 695. J Biol Chem 2001, 276:21562-21570.

87. Janus C, Pearson J, McLaurin J, Mathews PM, Jiang Y, Schmidt SD, Chishti MA, Horne P, Heslin D, French J, Mount HT, Nixon RA, Mercken M, Bergeron C, Fraser PE, St George-Hyslop P, Westaway D: A beta peptide immunization reduces behavioural impairment and plaques in a model of Alzheimer's disease. Nature 2000, 408:979-982.

88. Gortz N, Lewejohann L, Tomm M, Ambree O, Keyvani K, Paulus W, Sachser N: Effects of environmental enrichment on exploration, anxiety, and memory in female TgCRND8 Alzheimer mice. Behav Brain Res 2008, 191:43-48.

89. Richter H, Ambree O, Lewejohann L, Herring A, Keyvani K, Paulus W, Palme R, Touma C, Schabitz WR, Sachser N: Wheel-running in a transgenic mouse model of Alzheimer's disease: protection or symptom? Behav Brain Res 2008, 190:74-84.

90. Bellucci A, Luccarini I, Scali C, Prosperi C, Giovannini MG, Pepeu G, Casamenti $\mathrm{F}$ : Cholinergic dysfunction, neuronal damage and axonal loss in TgCRND8 mice. Neurobiol Dis 2006, 23:260-272.

91. Lovasic $L$, Bauschke $H$, Janus C: Working memory impairment in a transgenic amyloid precursor protein TgCRND8 mouse model of Alzheimer's disease. Genes Brain Behav 2005, 4:197-208.

92. Janus C: Search strategies used by APP transgenic mice during navigation in the Morris water maze. Learn Mem 2004, 11:337-346.

93. Hanna A, Horne P, Yager D, Eckman C, Eckman E, Janus C: Amyloid beta and impairment in multiple memory systems in older transgenic APP TgCRND8 mice. Genes Brain Behav 2009, 8:676-684.

94. Harris JA, Devidze N, Halabisky B, Lo I, Thwin MT, Yu GQ, Bredesen DE, Masliah E, Mucke L: Many neuronal and behavioral impairments in transgenic mouse models of Alzheimer's disease are independent of caspase cleavage of the amyloid precursor protein. J Neurosci 2010, 30:372-381.

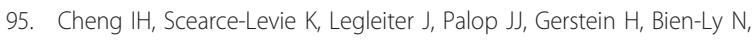
Puolivali J, Lesne S, Ashe KH, Muchowski PJ, Mucke L: Accelerating amyloid-beta fibrillization reduces oligomer levels and functional deficits in Alzheimer disease mouse models. J Biol Chem 2007, 282:23818-23828.

96. Sanchez-Mejia RO, Newman JW, Toh S, Yu GQ, Zhou Y, Halabisky B, Cisse M, Scearce-Levie K, Cheng IH, Gan L, Palop JJ, Bonventre JV, Mucke L: Phospholipase $\mathrm{A} 2$ reduction ameliorates cognitive deficits in a mouse model of Alzheimer's disease. Nat Neurosci 2008, 11:1311-1318.

97. Saura CA, Chen G, Malkani S, Choi SY, Takahashi RH, Zhang D, Gouras GK, Kirkwood A, Morris RG, Shen J: Conditional inactivation of presenilin 1 prevents amyloid accumulation and temporarily rescues contextual and spatial working memory impairments in amyloid precursor protein transgenic mice. J Neurosci 2005, 25:6755-6764.

98. Lustbader JW, Cirilli M, Lin C, Xu HW, Takuma K, Wang N, Caspersen C, Chen X, Pollak S, Chaney M, Trinchese F, Liu S, Gunn-Moore F, Lue LF, Walker DG, Kuppusamy P, Zewier ZL, Arancio O, Stern D, Yan SS, Wu H: $A B A D$ directly links $A \beta$ to mitochondrial toxicity in Alzheimer's disease. Science 2004, 304:448-452.

99. Meilandt WJ, Yu GQ, Chin J, Roberson ED, Palop JJ, Wu T, Scearce-Levie K, Mucke L: Enkephalin elevations contribute to neuronal and behavioral impairments in a transgenic mouse model of Alzheimer's disease. J Neurosci 2008, 28:5007-5017.

100. Simon AM, Schiapparelli L, Salazar-Colocho P, Cuadrado-Tejedor M, Escribano L, Lopez de Maturana R, Del Rio J, Perez-Mediavilla A, Frechilla D: Overexpression of wild-type human APP in mice causes cognitive deficits and pathological features unrelated to $A \beta$ levels. Neurobiol Dis 2009, 33:369-378.
101. Du H, Guo L, Zhang W, Rydzewska M, Yan S: Cyclophilin D deficiency improves mitochondrial function and learning/memory in aging Alzheimer disease mouse model. Neurobiol Aging 2011, 32:398-406.

102. Cisse M, Sanchez PE, Kim DH, Ho K, Yu GQ, Mucke L: Ablation of cellular prion protein does not ameliorate abnormal neural network activity or cognitive dysfunction in the $\mathrm{J} 20$ line of human amyloid precursor protein transgenic mice. J Neurosci 2011, 31:10427-10431.

103. Palop JJ, Jones B, Kekonius L, Chin J, Yu GQ, Raber J, Masliah E, Mucke L: Neuronal depletion of calcium-dependent proteins in the dentate gyrus is tightly linked to Alzheimer's disease-related cognitive deficits. Proc Natl Acad Sci USA 2003, 100:9572-9577.

104. Fang F, Chen X, Huang T, Lue LF, Luddy JS, Yan SS: Multi-faced neuroprotective effects of Ginsenoside Rg1 in an Alzheimer mouse model. Biochim Biophys Acta 2012, 1822:286-292.

105. Murakami K, Yokoyama S, Murata N, Ozawa Y, Irie K, Shirasawa T, Shimizu T: Insulin receptor mutation results in insulin resistance and hyperinsulinemia but does not exacerbate Alzheimer's-like phenotypes in mice. Biochem Biophys Res Commun 2011, 409:34-39.

106. Escribano L, Simon AM, Perez-Mediavilla A, Salazar-Colocho P, Del Rio J, Frechilla D: Rosiglitazone reverses memory decline and hippocampal glucocorticoid receptor down-regulation in an Alzheimer's disease mouse model. Biochem Biophys Res Commun 2009, 379:406-410.

107. Karl T, Bhatia S, Cheng D, Kim WS, Garner B: Cognitive phenotyping of amyloid precursor protein transgenic J20 mice. Behav Brain Res 2012, 228:392-397.

108. Galvan V, Gorostiza OF, Banwait S, Ataie M, Logvinova AV, Sitaraman S, Carlson E, Sagi SA, Chevallier N, Jin K, Greenberg DA, Bredesen DE: Reversal of Alzheimer's-like pathology and behavior in human APP transgenic mice by mutation of Asp664. Proc Natl Acad Sci USA 2006, 103:7130-7135.

109. Xu F, Grande AM, Robinson JK, Previti ML, Vasek M, Davis J, Van Nostrand WE: Early-onset subicular microvascular amyloid and neuroinflammation correlate with behavioral deficits in vasculotropic mutant amyloid beta-protein precursor transgenic mice. Neuroscience 2007, 146:98-107.

110. Fan R, Xu F, Previti ML, Davis J, Grande AM, Robinson JK, Van Nostrand WE: Minocycline reduces microglial activation and improves behavioral deficits in a transgenic model of cerebral microvascular amyloid. J Neurosci 2007, 27:3057-3063.

111. Lalonde R, Kim HD, Fukuchi K: Exploratory activity, anxiety, and motor coordination in bigenic APPswe + PS1/DeltaE9 mice. Neurosci Lett 2004, 369:156-161.

112. Cao D, Lu H, Lewis TL, Li L: Intake of sucrose-sweetened water induces insulin resistance and exacerbates memory deficits and amyloidosis in a transgenic mouse model of Alzheimer disease. J Biol Chem 2007, 282:36275-36282.

113. Reiserer RS, Harrison FE, Syverud DC, McDonald MP: Impaired spatial learning in the APPSwe + PSEN1DeltaE9 bigenic mouse model of Alzheimer's disease. Genes Brain Behav 2007, 6:54-65.

114. Cramer PE, Cirrito JR, Wesson DW, Lee CY, Karlo JC, Zinn AE, Casali BT, Restivo JL, Goebel WD, James MJ, Brunden KR, Wilson DA, Landreth GE: ApoE-directed therapeutics rapidly clear beta-amyloid and reverse deficits in AD mouse models. Science 2012, 335:1503-1506.

115. Volianskis A, Kostner R, Molgaard M, Hass S, Jensen MS: Episodic memory deficits are not related to altered glutamatergic synaptic transmission and plasticity in the CA1 hippocampus of the APPswe/PS1deltaE9deleted transgenic mice model of ss-amyloidosis. Neurobiol Aging 2010, 31:1173-1187.

116. Ding Y, Qiao A, Wang Z, Goodwin JS, Lee ES, Block ML, Allsbrook M, McDonald MP, Fan GH: Retinoic acid attenuates beta-amyloid deposition and rescues memory deficits in an Alzheimer's disease transgenic mouse model. J Neurosci 2008, 28:11622-11634.

117. Bernardo A, Harrison FE, McCord M, Zhao J, Bruchey A, Davies SS, Jackson Roberts L, Mathews PM, Matsuoka Y, Ariga T, Yu RK, Thompson R, McDonald MP: Elimination of GD3 synthase improves memory and reduces amyloid-beta plaque load in transgenic mice. Neurobiol Aging 2009, 30:1777-1791.

118. Ma T, Du X, Pick JE, Sui G, Brownlee M, Klann E: Glucagon-like peptide-1 cleavage product GLP-1(9-36) amide rescues synaptic plasticity and memory deficits in Alzheimer's disease model mice. J Neurosci 2012, 32:13701-13708. 
119. Lalonde R, Kim HD, Maxwell JA, Fukuchi K: Exploratory activity and spatial learning in 12-month-old APP(695)SWE/co+PS1/DeltaE9 mice with amyloid plaques. Neurosci Lett 2005, 390:87-92.

120. Zhang W, Hao J, Liu R, Zhang Z, Lei G, Su C, Miao J, Li Z: Soluble A levels correlate with cognitive deficits in the 12-month-old APPswe/PS1dE9 mouse model of Alzheimer's disease. Behav Brain Res 2011, 222:342-350.

121. Knafo S, Venero C, Merino-Serrais P, Fernaud-Espinosa I, Gonzalez-Soriano J, Ferrer I, Santpere G, DeFelipe J: Morphological alterations to neurons of the amygdala and impaired fear conditioning in a transgenic mouse model of Alzheimer's disease. J Pathol 2009, 219:41-51.

122. O'Leary TP, Brown RE: Visuo-spatial learning and memory deficits on the Barnes maze in the 16-month-old APPswe/PS1dE9 mouse model of Alzheimer's disease. Behav Brain Res 2009, 201:120-127.

123. Holcomb L, Gordon MN, McGowan E, Yu X, Benkovic S, Jantzen P, Wright K, Saad I, Mueller R, Morgan D, Sanders S, Zehr C, O'Campo K, Hardy J, Prada CM, Eckman C, Younkin S, Hsiao K, Duff K: Accelerated Alzheimertype phenotype in transgenic mice carrying both mutant amyloid precursor protein and presenilin 1 transgenes. Nat Med 1998, 4:97-100.

124. Sadowski M, Pankiewicz J, Scholtzova H, Ji Y, Quartermain D, Jensen CH, Duff K, Nixon RA, Gruen RJ, Wisniewski T: Amyloid-beta deposition is associated with decreased hippocampal glucose metabolism and spatial memory impairment in APP/PS1 mice. J Neuropathol Exp Neurol 2004, 63:418-428.

125. Holcomb LA, Gordon MN, Jantzen P, Hsiao K, Duff K, Morgan D: Behavioral changes in transgenic mice expressing both amyloid precursor protein and presenilin-1 mutations: lack of association with amyloid deposits. Behav Genet 1999, 29:177-185.

126. Mori T, Koyama N, Guillot-Sestier MV, Tan J, Town T: Ferulic acid is a nutraceutical beta-secretase modulator that improves behavioral impairment and Alzheimer-like pathology in transgenic mice. PLoS One 2013, 8:e55774.

127. Gordon MN, King DL, Diamond DM, Jantzen PT, Boyett KV, Hope CE, Hatcher JM, DiCarlo G, Gottschall WP, Morgan D, Arendash GW: Correlation between cognitive deficits and A $\beta$ deposits in transgenic APP+PS1 mice. Neurobiol Aging 2001, 22:377-385.

128. Wilcock DM, Rojiani A, Rosenthal A, Subbarao S, Freeman MJ, Gordon MN, Morgan D: Passive immunotherapy against $A \beta$ in aged APP-transgenic mice reverses cognitive deficits and depletes parenchymal amyloid deposits in spite of increased vascular amyloid and microhemorrhage. J Neuroinflammation 2004, 1:24

129. Oakley H, Cole SL, Logan S, Maus E, Shao P, Craft J, Guillozet-Bongaarts A, Ohno M, Disterhoft J, Van Eldik L, Berry R, Vassar R: Intraneuronal betaamyloid aggregates, neurodegeneration, and neuron loss in transgenic mice with five familial Alzheimer's disease mutations: potential factors in amyloid plaque formation. J Neurosci 2006, 26:10129-10140.

130. Jawhar S, Trawicka A, Jenneckens C, Bayer TA, Wirths O: Motor deficits, neuron loss, and reduced anxiety coinciding with axonal degeneration and intraneuronal $A \beta$ aggregation in the 5XFAD mouse model of Alzheimer's disease. Neurobiol Aging 2012, 33:196.e129-e140.

131. Shukla V, Zheng YL, Mishra SK, Amin ND, Steiner J, Grant P, Kesavapany S, Pant HC: A truncated peptide from p35, a Cdk5 activator, prevents Alzheimer's disease phenotypes in model mice. FASEB J 2013, 27:174-186.

132. Ohno M, Chang L, Tseng W, Oakley H, Citron M, Klein WL, Vassar R, Disterhoft JF: Temporal memory deficits in Alzheimer's mouse models: rescue by genetic deletion of BACE1. Eur J Neurosci 2006, 23:251-260.

133. Wirths O, Erck C, Martens H, Harmeier A, Geumann C, Jawhar S, Kumar S, Multhaup G, Walter J, Ingelsson M, Degerman-Gunnarsson M, Kalimo H, Huitinga I, Lannfelt L, Bayer TA: Identification of low molecular weight pyroglutamate A[44] oligomers in Alzheimer disease: a novel tool for therapy and diagnosis. J Biol Chem 2010, 285:41517-41524.

134. Devi L, Ohno M: Genetic reductions of beta-site amyloid precursor protein-cleaving enzyme 1 and amyloid-beta ameliorate impairment of conditioned taste aversion memory in 5XFAD Alzheimer's disease model mice. Eur J Neurosci 2010, 31:110-118.

135. Devi L, Ohno M: Mitochondrial dysfunction and accumulation of the beta-secretase-cleaved C-terminal fragment of APP in Alzheimer's disease transgenic mice. Neurobiol Dis 2012, 45:417-424.

136. Tohda C, Urano T, Umezaki M, Nemere I, Kuboyama T: Diosgenin is an exogenous activator of 1,25D(3)-MARRS/Pdia3/ERp57 and improves Alzheimer's disease pathologies in 5XFAD mice. Sci Rep 2012, 2:535.
137. Urano T, Tohda C: Icariin improves memory impairment in Alzheimer's disease model mice (5xFAD) and attenuates amyloid beta-induced neurite atrophy. Phytother Res 2010, 24:1658-1663.

138. Billings LM, Oddo S, Green KN, McGaugh JL, LaFerla FM: Intraneuronal A $\beta$ causes the onset of early Alzheimer's disease-related cognitive deficits in transgenic mice. Neuron 2005, 45:675-688.

139. Clinton LK, Billings LM, Green KN, Caccamo A, Ngo J, Oddo S, McGaugh JL, LaFerla FM: Age-dependent sexual dimorphism in cognition and stress response in the 3xTg-AD mice. Neurobiol Dis 2007, 28:76-82.

140. Gimenez-Llort L, Blazquez G, Canete T, Johansson B, Oddo S, Tobena A, LaFerla FM, Fernandez-Teruel A: Modeling behavioral and neuronal symptoms of Alzheimer's disease in mice: a role for intraneuronal amyloid. Neurosci Biobehav Rev 2007, 31:125-147.

141. Carroll JC, Rosario ER, Chang L, Stanczyk FZ, Oddo S, LaFerla FM, Pike CJ: Progesterone and estrogen regulate Alzheimer-like neuropathology in female 3xTg-AD mice. J Neurosci 2007, 27:13357-13365.

142. Nelson RL, Guo Z, Halagappa VM, Pearson M, Gray AJ, Matsuoka Y, Brown M, Martin B, lyun T, Maudsley S, Clark RF, Mattson MP: Prophylactic treatment with paroxetine ameliorates behavioral deficits and retards the development of amyloid and tau pathologies in 3xTgAD mice. Exp Neurol 2007, 205:166-176

143. Pietropaolo S, Feldon J, Yee BK: Age-dependent phenotypic characteristics of a triple transgenic mouse model of Alzheimer disease. Behav Neurosci 2008, 122:733-747.

144. Pietropaolo S, Sun Y, Li R, Brana C, Feldon J, Yee BK: Limited impact of social isolation on Alzheimer-like symptoms in a triple transgenic mouse model. Behav Neurosci 2009, 123:181-195.

145. Sterniczuk R, Antle MC, Laferla FM, Dyck RH: Characterization of the 3xTgAD mouse model of Alzheimer's disease: part 2. Behavioral and cognitive changes. Brain Res 2010, 1348:149-155.

146. Arsenault D, Julien C, Tremblay C, Calon F: DHA improves cognition and prevents dysfunction of entorhinal cortex neurons in 3xTg-AD mice. PLoS One 2011, 6:e17397.

147. Filali M, Lalonde R, Theriault P, Julien C, Calon F, Planel E: Cognitive and non-cognitive behaviors in the triple transgenic mouse model of Alzheimer's disease expressing mutated APP, PS1, and Mapt (3xTg-AD). Behav Brain Res 2012, 234:334-342.

148. Stewart S, Cacucci F, Lever C: Which memory task for my mouse? A systematic review of spatial memory performance in the Tg2576 Alzheimer's mouse model. J Alzheimers Dis 2011, 26:105-126.

149. Gulinello M, Gertner M, Mendoza G, Schoenfeld BP, Oddo S, LaFerla F, Choi CH, McBride SM, Faber DS: Validation of a 2-day water maze protocol in mice. Behav Brain Res 2009, 196:220-227.

150. Halagappa VK, Guo Z, Pearson M, Matsuoka Y, Cutler RG, Laferla FM, Mattson MP: Intermittent fasting and caloric restriction ameliorate agerelated behavioral deficits in the triple-transgenic mouse model of Alzheimer's disease. Neurobiol Dis 2007, 26:212-220.

151. Games D, Adams D, Alessandrini R, Barbour R, Berthelette P, Blackwell C, Carr T, Clemens J, Donaldson T, Gillespie F, Guido T, Hagopian S, Johnson-Wood K, Khan K, Lee M, Leibowitz P, Lieberburg I, Little S, Masliah E, McConlogue L, Montoya-Zavala M, Mucke L, Paganini L, Penniman E, Power M, Schenk D, Seubert P, Snyder B, Soriano F, Tan H, et al: Alzheimer-type neuropathology in transgenic mice overexpressing V717F beta-amyloid precursor protein. Nature 1995, 373:523-527.

152. Sturchler-Pierrat C, Abramowski D, Duke M, Wiederhold KH, Mistl C, Rothacher S, Ledermann B, Burki K, Frey P, Paganetti PA, Waridel C, Calhoun ME, Jucker M, Probst A, Staufenbiel M, Sommer B: Two amyloid precursor protein transgenic mouse models with Alzheimer disease-like pathology. Proc Natl Acad Sci USA 1997, 94:13287-13292.

153. Mucke L, Masliah E, Yu GQ, Mallory M, Rockenstein EM, Tatsuno G, Hu K, Kholodenko D, Johnson-Wood K, McConlogue L: High-level neuronal expression of a $1-42$ in wild-type human amyloid protein precursor transgenic mice: synaptotoxicity without plaque formation. J Neurosci 2000, 20:4050-4058.

154. Davis J, Xu F, Deane R, Romanov G, Previti ML, Zeigler K, Zlokovic BV, Van Nostrand WE: Early-onset and robust cerebral microvascular accumulation of amyloid beta-protein in transgenic mice expressing low levels of a vasculotropic Dutch/lowa mutant form of amyloid betaprotein precursor. J Biol Chem 2004, 279:20296-20306. 
155. Jankowsky JL, Slunt HH, Ratovitski T, Jenkins NA, Copeland NG, Borchelt DR: Co-expression of multiple transgenes in mouse CNS: a comparison of strategies. Biomol Eng 2001, 17:157-165.

156. Oddo S, Caccamo A, Shepherd JD, Murphy MP, Golde TE, Kayed R, Metherate R, Mattson MP, Akbari Y, LaFerla FM: Triple-transgenic model of Alzheimer's disease with plaques and tangles: intracellular $A \beta$ and synaptic dysfunction. Neuron 2003, 39:409-421.

doi:10.1186/alzrt182

Cite this article as: Webster et al:: Comprehensive behavioral

characterization of an APP/PS-1 double knock-in mouse model of Alzheimer's disease. Alzheimer's Research \& Therapy 2013 5:28.

Submit your next manuscript to BioMed Central and take full advantage of:

- Convenient online submission

- Thorough peer review

- No space constraints or color figure charges

- Immediate publication on acceptance

- Inclusion in PubMed, CAS, Scopus and Google Scholar

- Research which is freely available for redistribution

Submit your manuscript at www.biomedcentral.com/submit 